\title{
Mothers Doing Religion
}

\section{Gendered Habitus and Domestic Religion}

Gender is one of the most fundamental social classifications. Bourdieuan readings of gender proceed from the premise that the gendered division of labor is embodied in habitus (Bourdieu 2001, 8-9; see also Krais 2006, 120-121; McNay 2000, 38-39). As part of habitus, gender identity is acquired and enacted largely at a pre-reflective level. It is therefore relatively stable. At the same time, participation in multiple fields subjects the individual to various symbolic formations of masculinity and femininity, for gender is differently entwined into the organization of different social fields (Krais 2006, 128, 131; McNay 2000, 53-57; McNay 1999, 107-108). As a result, gendered habitus is infused with a degree of ambiguity.

The family forms a central site for the production of gendered habitus. Virtually every individual internalizes a certain understanding of the family and the dynamics between family members during their primary socialization (Bourdieu 1996, 21-25). In his work, Bourdieu (e.g., 2001, 85; 1996, 23-24) sometimes speaks of the family as a field, acknowledging the role of the gender classification as its central organizing principle. However, as Lois McNay $(2000,70-71 ; 1999,112-113)$ has suggested, gender can actually be seen to figure in at least two distinct struggles situated within the sphere of the family. First, it affects struggles pertaining to the domestic division of labor. Second, it also influences struggles focusing on the emotional bonds between family members.

Religion as a social phenomenon takes place within the gender order of any given society. Often, religion helps to define and legitimate power relations between the sexes. In most (but not all) cases, official religious discourses and structures constitute women as somehow inferior to men. ${ }^{1}$ The lived religion

1 The pan-Christian conceptualization of the relationship between the sexes oscillates between two ideas: equivalence and hierarchy (e.g., Ruether 1987, 207-215). On the one hand, both man and woman are considered to have been created as images of God. On the other, women are often portrayed as inferior to men and even as evil beings, particularly as regards their sexuality. In Orthodox Christian thought, the relationship between husband and wife is seen to be based on the different but complementary roles of the sexes (Kollontai 2000, 166-168). Following Apostle Paul's formulation, the role of man is to be the head, and the role 
of individuals does not necessarily comply with prescribed gender classifications; nevertheless, the religious lives of women and men are intertwined with their socioculturally formed roles, desires, and life trajectories. Women's religious activities have traditionally paralleled women's interpersonal concerns within the context of the family (Cozad 1999, 679-680; Sered 1994, 5, 71-72; Woodhead 2002, 333). They have emphasized women's responsibilities as mothers and as caretakers of the home. During the past 50 years, the distribution of power between men and women in Western societies has gone through marked changes. However, even the so-called gender revolution has not been able to obliterate women's ties to their traditional gender roles (Beck and BeckGernsheim 2002, 55-56; McNay 1999, 103).

In this chapter, I analyze the evacuee Karelian Orthodox women's interview accounts with regard to religion in the adult family (i.e., the family established as an adult) environment. From these accounts, I identify ways in which the women's religious activities structured domestic and personal relations within their families. The accounts depict the women doing religion as mothers and wives; hence, they illustrate particularly well the influence of the interviewees' gendered habitus on their religion. Religiosity in adulthood is built on childhood socialization into religion and gender roles. Nevertheless, habitus continues to develop even during adulthood. In the course of the chapter, I alternate between approaching the women's accounts as evidence of their past practices and social trajectories and as suggestive of their current habitus.

In their adult families, the interviewees seem to have shouldered the primary responsibility for taking care of the home and the children. In the interviews, they spontaneously described juggling between work and domestic duties when their children had been underage. This double burden had taken a toll on their personal religious lives as well. Tarja, for instance, explained: "Marriage and work dominated then. And later on, I traveled a lot at work and ... Religion receded to the background. I just didn't have the capacity." And Katri stated: "You had no time to think of anything else besides earning your daily bread and taking care of the family." In statements such as these, the women gave to understand that their religious practice had been crippled by external circumstances that they could not overcome.

That childcare fell mainly to the women was also implied in accounts concerning religious practice. Soja, for instance, stated: "When the children were small, I couldn't always go [to church]. I was just here at home ... and sometimes I took the children with me. But it was difficult." Soja, that is, does not

of woman is to be man's helper. Motherhood and motherliness are seen as intrinsic to being a woman (Limberis 1999, 752; Raunistola-Juutinen 2012, 127-133, 198). 
even entertain the possibility that her husband could have looked after the children. Lempi, for her part, remembered: "When the children were home, and I had the chance [to go to Orthodox service] only once a month, my husband was nice enough to stay at home with the bunch." The noteworthy thing about her description is that she does not view her husband's willingness to stay at home with the kids as something self-evident, but as something he was "nice enough" to do. The expression reveals Lempi's gratitude to her husband for doing something that, in their domestic division of labor, was not exactly his responsibility (see also Hochschild with Machung 2003, 19).

The examples above convey the general tone with which the women spoke of their religious practice within their adult families. They, in a word, placed their responsibilities as caretakers of their loved ones before their personal lives. According to previous research, the prevalence of such an altruistic ethos is typical of the life narratives of Finnish women of the inter-World War generation (Kortteinen 1992, 47-48, 63-72; Olsson 2011, 121-125; Strandell 1984, 223-224).

In the interviews, I did not systematically question the women about their domestic responsibilities. The interviewees, moreover, rarely problematized the gendered division of labor within their families. They did not produce comparisons between their workload and that of their spouses, other parents, or other women, or even describe taking on specific tasks as a result of spouseto-spouse negotiations. Instead, they mostly spoke of their roles as caregivers as a fact that needed no explanation. It therefore seems that with respect to the gendered division of labor the women were not as acutely aware of alternatives as when it came to their religiosity. The matter-of-fact nature of the women's descriptions of their domestic responsibilities reflects the internalization of these responsibilities in their gendered habitus.

Bourdieu (2001, 33-42; see also 2000, 170-172, 177) considers the gendered division of labor a paradigmatic example of symbolic power. According to him, women's practical belief in established symbolic classifications constitutes a crucial feature of their subordination. Since they have internalized the prevalent social order, they cannot but conceive of their position in terms that affirm the hierarchy between the sexes. Many feminist scholars have argued that Bourdieu's theorization of the gender order is overly pessimistic as regards the possibility of change (Fowler 2003, 473-474, 477-478; Krais 2006, 122-124; Lovell 2000, 30-31; McNay 2004, 180-183). Nevertheless, his notion of symbolic power provides a persuasive explanation as to why individuals - including the women of my study - often adhere to symbolic structures that disadvantage them. 
In the modern Western division of labor between the sexes, everyday responsibility over religion has, to a certain extent, been assigned to women (Woodhead 2007, 578-579). In the interviews, I asked the informants about their roles with regard to the religious lives of their adult families. The answers established the women as the ones running collective religious practice. Whereas some interviewees mentioned agreeing on matters of religion with their spouses, others noted that there had been no need for negotiation in the first place. Commonly, the women underlined that, as to religion, their family lives were characterized by an atmosphere of "mutual understanding." This consensus was emphasized by women in all-Orthodox and mixed marriages alike. Rauha, for instance, stated: "We, in our family, we had no disagreements as to religion." And Esteri remembered: "Whatever I did, it was ok [by my husband]. There were no difficulties."

The modern Western gender order also construes women as responsible for the inter-personal relations within the family (Bourdieu 2001, 97; Bourdieu 1996, 22; di Leonardo 1987, 442-443; Reay 2004a, 59-61). This responsibility was manifested also in the interviewees' descriptions of the tolerant religious atmosphere of their families.

Maija-Liisa: After a while, I became fascinated by icons. I wanted to put an icon in our home; we lacked one. (...) I didn't manage to talk about it with my husband; what he thought about [having an icon]. In all quietness, I put an icon on the bedside table, made it just slightly visible. If it was acceptable, I moved it a little higher up, placed it on a bookshelf. And from there, again, a little higher up... Little by little, and always listening to his reactions.

In the excerpt above, Maija-Liisa describes in a particularly forthcoming way how she maneuvered to make Orthodoxy more visible in her home without arousing disagreements with her husband. Her account sheds light on how avoiding conflicts could form a central guiding principle of the interviewees' doing of religion within the adult family context. Since concord between spouses was important to them, they did not risk disrupting it. Quite the contrary, they nurtured peaceful relations with family members even as part of their religious practice. In the same vein, anthropologist Susan Starr Sered $(1994,83-84)$ has argued that women tend to praise harmonious interpersonal relationships in their religious activities, and to demonstrate religious flexibility in order to avoid religion-based conflicts within their immediate social circle. 
Overall, there was a lot of variation in how the women spoke about religious activities within their adult families. A few interviewees described this theme eagerly, emphasizing the strong presence of religion within their homes. Many, however, did not want to dwell on the topic. Some kept their answers short and non-specific to protect their family members' privacy. Others, for their part, seemed to evade the topic for fear that religion had not figured in the lives of their families to the extent that that they thought (I thought) was proper. On the whole, the adult family was clearly one of the more delicate themes of the interview frame. The fact that I did not have children of my own created an asymmetry between the informants and myself that was not easy to overcome over the course of a single interview (cf., Honkasalo 2015, 66-67, 86).

Throughout the interviews, the women spoke of their marriages in a favorable way. With few exceptions, the only women who made any negative remarks were those who had at some point divorced their spouses. These interviewees might spontaneously take up, for instance, the alcoholism or infidelity of their husbands to justify the break-up of their marriages. Nevertheless, generally speaking the women took care to build a positive picture of their families, including their (deceased) husbands. The informants' stress on familial concord showed, among other things, in their treatment of the Lutheran affiliation of their husbands and children. Whereas the women commonly expressed their outlook towards Lutheranism by remarking on how it differed from Orthodoxy, when speaking of the co-existence of the denominations within their homes they tended to stress the commonalities between the two faiths. For this purpose, they used phrases emphasizing the fundamental unity of the denominations - noting, for instance, that Orthodox and Lutherans "had the same God." These phrases were employed to establish the point that, as to religion, the Lutheran and Orthodox members of the family were ultimately on the same side.

Virtually all the interviewees also described their husbands' attitudes towards Orthodox Christianity in positive or neutral tones. ${ }^{2}$ The women's

2 The only informant who gave a clearly negative account of her husband in this respect had married an Orthodox man. However, the husband's mother having been Lutheran, he had not been accustomed to Orthodox customs. Thus, the woman in question stated, for instance, that he "didn't respect icons, or tolerate them." I find it interesting that, in all of the material, the most outspoken husband's criticism of Orthodoxy is reported by a woman with an Orthodox husband. Maybe it was somehow easier for this woman to bring up a negative issue since she wasn't talking about a mixed marriage? At any rate, she did not have a point to prove about her marriage as a ground for harmonious religious life: in theory, a marriage of two people of the same denominational affiliation is, after all, an ideal match. 
stress on the tolerance that their Lutheran spouses showed towards Orthodoxy makes sense in the light of the low status of the Church during the post-war period. Nevertheless, my overall impression was that some of the women actually censored their accounts when it came to familial discord. This behavior was yet another expression of the women's loyalty towards their adult families. It showed them acting as protectors of the family, including the family image, even in the interview situations.

\section{Navigations between Orthodoxy and Lutheranism}

When I interviewed Vieno, an 80-year-old from Kuopio, in North Savonia, she offered me leftover biscuits and cake from a family celebration that she had organized the previous weekend. She had recently moved into an apartment building for senior citizens in the center of town, and had invited a priest to consecrate her home. During the same visit, the priest had also conducted a memorial service for her husband, deceased for five years. Vieno expressed to me her deep satisfaction that her three children and four grandchildren had all attended the event. After all, occasions for such collective Orthodox practice were not common in her family.

Vieno's husband had been Lutheran and so were all her offspring. When her children were growing up, she had been very respectful of their religious affiliation. She noted, for instance, that she had not been able to teach them the sign of the cross "because they were Lutherans." Vieno's husband, moreover, had not been a churchgoer, and so it had been left to her to familiarize the children with Lutheran church life. "I tried to take them to the Lutheran church," she recounted, "it was always ... I was like 'oh, it isn't nice in here' (laughs). But [I did it] for the children. They had to be reared in their religion as much as possible." During the course of the interview, I also asked Vieno if her children's Lutheranism bothered her. Her answer was ambiguous. First, she stated that it did not, but then admitted that, had they been Orthodox, she could naturally have taught them so much more about religion. "But all three turned out fine Lutheran children anyway," as she ended her rumination on the topic.

Altogether 20 of the 24 interviewees had married Lutheran men. The women's descriptions of how they had combined their Orthodoxy with their roles as mothers of Lutheran families varied a great deal. Whereas some claimed to have continued to observe all their childhood practices in their adult families, others explained that they had advocated the minimal exposure of family 
members to Orthodoxy. Ilmi, for example, stated: "I didn't want the children to get conflicting ideas about religion. I tried to live according to the common way. (...) I didn't emphasize my side in any way." Between the lines of Ilmi's account shines the stigmatized status of Orthodoxy in post-war Finland.

Generally speaking, the women's basic tenet concerning Orthodox practice seems to have been to tailor their religious activity to fit the limited space at their disposal. The performance of personal practices such as making the sign of the cross and praying they described as the least governed by the family members' Lutheranism. The small-scale nature of these customs was a significant factor in the women's being able to continue their observance relatively undisturbed. Practices that required spare time, exemption from familial obligations, the invasion of domestic space, financial expenditure, or the presence of a religious specialist, were more problematic to follow. Some of the interviewees, for instance, conveyed that they had not arranged for their homes to be consecrated to avoid possible disagreements with their spouses.

The women's efforts to manage the collective religious lives of their families were characterized by alternation between Lutheran and Orthodox elements. Religious holidays were one instance that called for them to find a balance between the preferences of family members. Compared to everyday practices, religious celebrations require preparations: cleaning and decorating the home, cooking, organizing get-togethers, and so on. These preparations are integral to the celebrations themselves; they bring about the proper spatiotemporality within the sphere of the home (see Keinänen 2012; Keinänen 2010a). Judging from the interviews, the women were commonly in charge of holiday preparations as part of their domestic duties. This assignment gave them relative authority over the celebrations. Nevertheless, it did not translate into them following only Orthodox ways in preparing for the feasts. According to the interviewees, the possibility to observe at least some Orthodox traditions as part of the holidays was important to them. In the end, however, they had catered first and foremost to their Lutheran families.

In the previous chapter, I argued that the women's routinized religious practices should be understood as agentic actions with which they constituted their everyday life-world. The same thing can be said of their religious practices within the adult family context. Religion does not become a part of family life automatically but through concrete actions. Hence, the women's organizing activities were crucial in making religion into what it was for the family. Moreover, through their efforts to take into account the preferences of different family members, and to include the whole family in collective occasions of worship, the interviewees wove religion to the fabric of domestic life, attended to the continuance of family religious traditions - and did 
"kin work," constructed ties of emotion and intimacy between family members (di Leonardo 1987, 442-443; see also Bourdieu 2001, 97; Bourdieu 1996, 22). They often took charge of the continuance of the Lutheran traditions of their husband's kin as well as their own.

The interviewees' familial responsibilities included being in charge of the religious socialization of children. That the children's affiliation differed from theirs did not essentially affect this arrangement. In raising their Lutheran children, the women seem to have emphasized the common Christian base of Lutheran and Orthodox Churches. Lempi, for instance, stated: "I don't remember [teaching the children] any [Orthodox customs] but the sign of the cross, which they've adopted according their way (i.e., the Catholic/Protestant style). Everything else was probably pan-Christian." In some families, like Sinikka's, the focus was more specifically on Lutheran customs: "I did tell my child about my faith. (...) But he received a Lutheran upbringing." Yet another tactic was to refrain, more or less, from explicit religious teaching. This is exemplified by Esteri's account: “Well, we didn't really [teach the children about religion]. They all went to Sunday school and received those Sunday school badges, it was part of Lutheranism. I guess I didn't [teach them] about Orthodoxy either, since they were already Lutheran."

The women usually implied that the children's Lutheranism had limited the extent to which they had been introduced to the Orthodox ways. The informants' descriptions of specific practices betray their oscillation between a common Christian base and customs marked as Orthodox or Lutheran. The most often mentioned form of collective worship was praying. Praying was a custom easily shared with Lutheran children; even the women who hesitated to "confuse" their children's religious identity mentioned the teaching of prayers. However, when it came to the embodied gestures that are part of Lutheran and Orthodox practices of praying, things already got more complicated. Toini, for instance, stated: "I did [bless] my children, when they were younger, [before going] to school. In the mornings. But we pressed the palms of our hands together; there was no making of the sign of the cross." That is, she preferred to use the Lutheran gesture of prayer when praying with her children. A few interviewees, such as Vieno in the introductory vignette, also explicitly noted that they had refrained from teaching the sign of the cross to their Lutheran children.

On the whole, the women's accommodation to the Lutheranism of the rest of the family, their responsibilities concerning the religious life of that family, and the dominant status of Lutheranism in the surrounding society resulted in a kind of Lutheranization of their overall religious practice. The informants took part in Lutheran rituals, observed Lutheran customs, and were acquainted 
with the Lutheran ways. In this vein, Soja even remarked that as the mother of Lutheran children she "was both Lutheran and Orthodox" herself. On occasion, the women also described Lutheran customs as enriching their personal religiosity, mentioning, for instance, that hymns were a Lutheran tradition they cherished. Some practices, however, could feel alien to the informants even after a thorough exposure to them. Such was the case, for example, with Vieno and Lutheran church services.

In contrast, it was common for the women to note that, today, they were more able to practice religion on their own terms than before. Their religious activities, plain and simple, were no longer as tightly linked with their responsibilities as mothers and wives of Lutheran families. Furthermore, the informants could also maintain that since their children had reached adulthood more space had opened up for Orthodoxy in family get-togethers and celebrations. In some cases, the tables had turned in that priority was no longer given to the children's (Lutheran) traditions, but to those of the elderly mother. A good example were family celebrations such as the one described in the opening vignette. In addition, three of the interviewees had children who had converted to Orthodoxy in adult life. These convert children, and their children, made Orthodoxy figure in family traditions in a whole new way.

Individuals' actions are the result of practical strategizing that abides by the contours prescribed by the habitus. According to Bourdieu, habitus guides practice by providing the individual "conditioned and conditional freedom" of action (Bourdieu 1990b, 55; see also McNay 2000, 58; McNay 2003, 144). While it always positions some acts outside the realm of possibility, innumerable variations of action remain within the individual's grasp. Practices related to family religious life reflect wider social currents, but are always implemented within concrete family environments. Within their adult families, the Orthodox women seem to have decided on different courses of action relatively independently. ${ }^{3}$ However, judging from the interviews there was little actual decision-making going on. Rather, the women followed what they instinctively felt was the appropriate course of action in particular situations. It is therefore possible to read their accounts as descriptions of their practical strategizing as circumscribed by their gendered habitus.

In having to combine and navigate between Lutheran and Orthodox customs to manage the religious lives of their families, the women faced a situation that was, originally, not familiar to them. They had no previous experience

3 During the first post-war decades, both Orthodox and Lutheran clergy did, in fact, strive to influence people in mixed marriages, particularly in decisions concerning the baptism and religious socialization of children (Kananen 2010, 116, 179-183; Laitila 2009, 342, 345-346). 
of how these things were done; instead, they had to form new courses of action. In the last instance, there were as many different ways of organizing family religious life as there were informants. At the same time, the women were heavily restricted in their options by their embodied adherence to a gendered division of labor. The accounts show how they placed their responsibilities as mothers and wives (of Lutheran families) ahead of their responsibilities as (Orthodox) religious practitioners. Their descriptions of more recent events, for their part, suggest an increase in maneuverability. Due to changes in family dynamics and overall social surroundings, the interviewees had acquired more freedom to introduce Orthodox elements into the collective religious lives of their families.

\section{Collective and Individual Practicing}

One theme that the displaced Karelian Orthodox women often took up when speaking of religion within their adult families was how the family members had practiced religion together. When describing, for instance, religious holidays and churchgoing, they commonly designated the actor in question as "we," referring to the nuclear family. The pronoun was used slightly more often by the informants with all-Orthodox families, but it also recurred in the narratives of the women with Lutheran families.

In the women's accounts, the family "we" foregrounded shared religious life. This is evident, for instance, in Auli's depiction of her all-Orthodox family's practice of going to church: "Since we've lived close by to a church, we've gone to church, for instance, on Christmas Eve and during Easter, and so on. (...) We've always gone together, (...) it's such a wonderful thing; nowadays with the grandchildren always [we go] to church." Siiri described her and her Lutheran husband's churchgoing more modestly: "We both valued each other's [religion]; we had an ecumenical marriage. (...) We went to both churches, when we went. Neither of us was an avid churchgoer." Nevertheless, she, too, constructed an image of both spouses respecting the religion of the other and participating in religious activities on equal terms. On the whole, while possibilities for collective worship varied from family to family, the informants positively cherished all occasions and ways of doing religion together with their family members.

Generally speaking, in mixed marriages to make the "we" work required more compromises than in all-Orthodox families. For the benefit of the "we," some of the women had, at least at some point of their lives, adapted to the practices of the Lutheran parties, renouncing their own in the process. Sinikka, 
for example, reminisced: "At that point (when her child was young), I took part in Lutheran activities quite a lot. In a way, my Orthodox practice went down. I went less to our church and more to Lutheran church; we went there as a family." Sinikka's account is yet another example of the interviewees' tendency to conduct their religious lives with the family in mind. Although the account obviously carries a tone of regret, it also suggests that, for Sinikka, there was a certain value in going to church "as a family." For the sake of comparison, in Hilja's account the same emphasis on practicing religion as a family is combined, not with regret over the hegemony of Lutheranism, but with pride over the family's all-Orthodox traditions: "We had an Orthodox home, as they say. We had icons and we went to church. And we raised our children into Orthodoxy, starting from when they were small."

In the women's accounts, the nuclear family was not the only possible composition of collective familial religious practice. Rather, the family "we" could also include all the close kin: parents, siblings, and their families. One interviewee, for example, described a tradition of visiting graves together with the extended family on Christmas Eve. Moreover, the women might also note how they had, at some point, started taking their elderly parents to church regularly. Especially to the informants with Lutheran adult families, the mother's influence could be essential in rekindling their own Orthodox practice. The wish to please one's mother came up with respect to various customs, the women explaining, for instance, that they had had their current homes consecrated because "it was important to mother."

Furthermore, yet another "we" consisted of the informant and a religiously active sibling or in-law. In the account below, Maija-Liisa explains how she enjoyed taking part in church life with her Lutheran mother, Lutheran motherin-law, and Orthodox sister. She places great value on collective religious practice, suggesting that the experience of acting as a "we" is preferred to acting alone. That it is mostly Lutheran church life that the family members participate in is deemed ultimately immaterial.

Our women, the women in both our families, have always been more spiritual as such, and more active in spiritual life and church life. I've gone everywhere with my mother-in-law and also with my mother and... I've always enjoyed being able to participate in church life together, whether in Lutheran or...W Well, we seldom went to Orthodox church since none of the women belonged to the Orthodox Church except my sister.

Maija-Liisa's account, incidentally, is also a good example of the importance of female lineages to the women and their religious practice. Outside the nuclear 
family, the interviewees' collective familial religious practice commonly took place between female relatives: grandmothers, mothers, mothers-in-law, sisters, sisters-in-law, daughters, and so on.

The significance of the family collective is also evident in those descriptions that do not have "we" as subject. For example, it was common for the interviewees with Lutheran families to note how their spouse and children "came along" with them to the Orthodox Liturgy. This kind of phrasing treats church worship as more of a personal than a family affair. It takes seriously the fact that in an Orthodox service, the Lutheran family members were in some way outsiders - as were the women themselves in a Lutheran one. ${ }^{4}$ Nevertheless, the presence of others was considered a positive and important matter, for it testified to their religiosity and broad-mindedness. In the same vein, when describing their personal religious practice, the women often took note of the family members' tolerant and encouraging attitudes towards it. Anna, for example, stressed: "There were no obstructions [to my practices] of any kind." And Kirsti expressed praise: "I've been allowed unlimited freedom (...) to practice my religion." With these kinds of expressions, the interviewees gave their family members credit as facilitators of their religious practice. Had they opposed it, this would have made the women's activities much more difficult.

In a similar fashion, Lutheran family members could also be cast in the role of interested observers. The women noted with delight their husbands' curiosity towards Orthodox ways, and took satisfaction in their children's and grandchildren's knowledge of Orthodox practices. Faina, for instance, explained: "I've always had a small icon like that. And my children have known the thing about it, that it's an icon. And then I've always had candles to burn. For instance, the children got used to me burning candles on my parents' days of death. (...) They know all this." With these kinds of accounts, the women emphasized that, while the children's Lutheranism had prevented their active socialization into the Orthodox way of life, they were at least familiar with many Orthodox customs, having witnessed their mother's religious practice and religious celebrations of their maternal kin.

All in all, then, it seems that the women interpreted acknowledging, observing, and being accustomed to their religious customs as minimal ways of participating in them. What this suggests is that many of the interviewees were actually quite alone with their religious activities within their adult homes even if they rarely brought this up in the interviews. Maija-Liisa (who, above,

4 Lutherans cannot participate in the Eucharist, the Orthodox Holy Communion. This is often seen to constitute a problem for collective religious practice in mixed families (Huotari 1975, 102; Merras 1993, 98). 
noted that she enjoyed participating in Lutheran functions together with family members) was perhaps most candid of the women on the topic, mentioning how she "misses her family and her relatives" at Orthodox church services.

On a contrary note, when speaking of the evolution of their religious practice after their children had grown up, the women often mentioned a newfound freedom to practice religion by themselves and for themselves. The informants, in other words, rejoiced in the transformation of doing religion into a thing of their own, a time and an activity for themselves. Elvi, for instance, noted: "With increasing age, already when my husband was still alive, I started to take more part [in church life]. Now I'm so content that I have time. And that I can do whatever I want without anyone [interfering]." The women's descriptions concerning their changing religious activities in later life bring forth the individualistic aspect of their religion: their contentment over being able to practice religion on their own terms, even if this meant doing it alone.

The Orthodox women's descriptions concerning different combinations of familial religious activity can be treated as testimonies of their past conditions of religious practice. Alternatively, they can be analyzed as manners of speaking about religion, in which case they are suggestive of the women's habitusgenerated appreciations of religion.

Most of the women, as I established above, did not spontaneously reflect on the gendered division of labor between themselves and their husbands. The few exceptions to this trend often explicated their opinions by referring to Christian family discourses. Thus Raili, for example, stated: "Men and women have to have different roles, because otherwise they'd be the same. Otherwise, God would have made us similar." The accounts discussed here suggest that even those women who did not voice their views held similar ideas. They considered practicing religion "as a family" important, often more important than their personal spiritual pursuits. Moreover, the interviewees' childhood experiences of religion also established the family as the place in and the group with which to do religion. Seeking out every occasion for collective familial religious practice could thus constitute an effort to recreate, at least temporarily, this ideal state of affairs.

Finally, it is also worth considering whether the women conceived of religious agency as, to some extent, collective agency. Agentic capacities always emerge in social interaction; moreover, they can also depend on concrete collaboration between individuals (Emirbayer and Mische 1998, 973; see also Ortner 2006, 130-131; Utriainen, Hovi, and Broo 2012, 204-205). Judging from the interviews, the women understood doing religion as a "we," at least on some occasions, to be more rewarding and more effective than doing religion alone. This is why they found practicing religion together worthwhile, even at the cost of some of their personal religious preferences. 


\section{Motherhood, Ethics, and Agency}

In the interviews, I explicitly asked the displaced Karelian Orthodox women about the central guidelines in life that they had obtained from Orthodox Christianity. They usually answered by referring to one common saying or another, or by bringing up basic Christian doctrine, such as the Ten Commandments. None of them, however, included in their responses any elaborations on Orthodox theology, or even mentioned the theme of deification, the ultimate life objective according to Orthodox thought. (Actually, when I brought up the notion, they often considered it a far-off idea with respect to the lives of lay Orthodox..$^{5}$ ) By contrast, the women could frame their talk on the proper Orthodox way of life by noting how they lived by their mother's or grandmother's teachings. On the whole, it was typical for them to underline the exemplary piety of some of their older relatives (usually mothers, grandmothers, or godmothers) in their accounts. These examples locate the foundation of the interviewees' understanding of ethics in their childhood environment.

The informants described their tenets of a good life in modest and practical terms. Their life principles were geared towards the everyday life, and concerned questions such as how to get through different troubles and how to keep bad influences and impulses at bay. The women's logic stemmed from the (Pan-Christian) idea that individuals' actions cause them either to move closer to God or to drift away from Him (see Harrison 2008, 81-82). It was therefore important to monitor your actions: to "live decently," to "do more good than evil," to "not do things that felt wrong," and to live in a way that you could "die with a good conscience." In addition, the interviewees stressed that human beings are bound to make mistakes, which is why they are required to practice piety only "according to their abilities."

By far the most central theme in the women's accounts of ethics was their relationship with other people (see also Gilligan 1982). They often stressed values such as love, caring, respect, tolerance, acceptance, honesty, and forgiveness as the cornerstones of a good life. The women might also mention the negative form of the Golden Rule ('don't do to others what you don't want to be done to yourself") and the second part of the Commandment of Love

5 According to Orthodox theology, every human being is endowed with the image of God: a state that refers, among other things, to such human faculties as consciousness, reason, creativity, and perception. Moreover, through virtuous behavior human beings can approach and, in rare cases, acquire the likeness of God (Hamalis 2011b; Harrison 2008, 78-81; Ware 1964, 224-226). This process is known as deification. 
("love your neighbor as you love yourself") as important tenets to follow. All in all, principles related to harmonious relationships were understood to be, first and foremost, religious principles. In fact, several women maintained that love formed the core of the Orthodox message (see also McGuckin 2011): "The central principle is love as such. Love is at the center of everything." Sometimes, values such as tolerance and hospitality were also connected to the "Karelian way of life" of one's childhood.

Verbalized ethical principles do not incorporate the premises of individuals' actions in a straightforward way. Just like rules, they are a practice of speaking about one's actions. Nevertheless, they reflect individuals' appreciations concerning practices, and, through them, the constitution of their habitus. In the case of the Orthodox women, the parallels between their notions of ethics and their descriptions of adult family life are evident. Their care-centered values and interpersonal orientation supported their prioritizing the family over individualistic pursuits. In fact, their understanding of a good and pious life made it possible to interpret taking care of the family as a form of religious practice. This point was stressed, for instance, by Kirsti:

I've felt, with having this kind of a family (i.e., large) and all, that there's striving (kilvoittelu) in it. (...) You have to see to your lot, and I've tried to do it, and it has been enough. A person cannot be everything, follow arduous prayer schedules and go on pilgrimages and such. You have to see to your lot.

Whereas family was the first and foremost target of their care, the interviewees had also cared for other people in the course of their lives. For example, many had participated in or financed volunteer work organized by the Orthodox Church, or by some other faith group operating in their home town. In addition, the women also helped by visiting and running errands for ailing friends and neighbors. In this vein, Lyyli, for instance, stated: "I help people. I don't go to church much, but that's (i.e., helping is) something that I've known how to do. I always have someone that I help."

Official Christian discourses assign to women the responsibility for the physical and emotional care for others (McGuire 1997, 131-133; Woodhead 2007, 569-573). They discipline women to put the needs and preferences of others before their own - something that was also inherent in the interviewees' accounts discussed above. Concern over the well-being of loved-ones, however, is often also at the core of women-centered religious practices, translating into a practical and this-worldly orientation that informs women's religious and ethical lives as a whole (Sered 1994, 5, 145, 149-156; Walter and 
Davie 1998, 650-651; see also Gilligan 1982). Judging from the interviews, a focus on concrete relations with specific people within the context of everyday life also characterized the Orthodox women's sense of ethics.

The formation of the habitus of dominated social groups, Pierre Bourdieu states, is a process that turns necessities into virtues (Bourdieu and Wacquant 1992, 127-128; Bourdieu 199ob, 53-54; Bourdieu 1984, 177-183, 372-384). Members of these groups commonly have few resources at their disposal and few courses of action to choose from. In their habitus, the compulsions and prohibitions that follow from their social position translate into matching dispositions. When generating future practice, these dispositions guide individuals to immediately exclude those options that have, in the past, been impossible, and to embrace ones that have been inevitable. This process can also be seen to inform the perceptions and values of the women of my study. Their advocacy of altruism as the basis of virtuous behavior demonstrates their "taste for the necessary" (Bourdieu 1984, 178), so well did it parallel the socially prescribed contours of their lives.

The interviewees were saddled with the obligation to look after their families by the society around them, by the religious community, and by their family members and in-laws. It was a responsibility they had acquired already as children; many of them noted how their upbringing and status within the childhood family had differed from that of their brothers. All in all, to "see to this lot," as Kirsti put it, was a necessity for the women. To fail to do so would have induced such harsh sanctions that it was, in practice, impossible. Nevertheless, in the women's parlance, to put the family first was also a highly valued virtue. It was a necessity their habitus imbued with worth and significance, to such an extent that it justified their less active religious practice - even in an interview that focused on religion. The women's habitus, in this sense, was very much a "caring habitus," imbued with a heightened will and a pronounced capacity to provide care for diverse others (Hirvonen 2014, 39-41).

The modern Western conceptualization of agency ties the possibility of agentic action with freedom and power (e.g., Meyer and Jepperson 2000, 100-101). During recent years, however, this liberalist understanding of agency has been increasingly criticized within social sciences. One of these critics is Talal Asad, who has pointed out that various religious traditions involve culturally meaningful approaches to disempowerment and suffering, which can transform these experiences from passive states to agentic action (Asad 2003, 70-72, 79, 84, 91-92). In her account of agency, Marja-Liisa Honkasalo (2015, 69-73; 2008a, 499-500; 2008b, 216-221) suggests that activities such as tolerating, enduring, and refraining from action can be understood as minimal forms of agency. In particular, these activities constitute agentic action when their 
observation involves a realization of the ethical valuations that the subject has internalized. In other words, they are agentic in so far as they comprise what Michel Foucault (2000) has called "techniques of the self": practices through which the individual hones his or her skills for performing ethical actions, whilst fulfilling his or her ideals of a good life.

My interviewees were also sometimes called to disempowerment and passivity to act in accordance with their notions of a good life. The women's deep-seated understanding of how to cultivate virtuous behavior made it possible for them to view the sacrifice of one's personal religious life as pious, at least to some extent. This sense of ethics is often evident, for instance, in their accounts concerning religious activity in the context of their adult families. In these accounts, the women often described their overall circumstances as highly restrictive, resulting in limited capacities for action.

Vieno: Many [Christmases] we celebrated with his (the husband's) family. I baked something to bring along, (...) pasties and casseroles and such. And then mummi always turned, we used to call mother-in-law mummi, she turned the radio up really loud to hear those (Lutheran) Christmas hymns and such. And I just can't, having small children, go to church. I have to stay there, with the children. You can also live Christmas in your mind.

In her account, Vieno laments that it was not possible for her to attend Orthodox church at Christmas when her children were small. However, the phrasing of the account implies that it was also Vieno herself who felt that she must prioritize her children, and spend the whole Christmas with them rather than go to church. The force of this moral judgment is enhanced by her switching to the present tense when speaking of how she "has" to stay at home with the children. Vieno's account, then, is an example of how the women's notions of a good life and good motherhood restricted their agentic possibilities in a very concrete sense. In this case, they created a situation in which the only ethical choice available was to refrain from going to church. Nevertheless, for Vieno, abiding by this choice was ultimately a way of enacting her understanding of virtuous behavior. According to the women's moral compass, after all, doing motherhood came first and doing religion second - and doing motherhood could sometimes encompass the doing of religion.

Yet another interesting element in Vieno's account is her statement that it is possible to "live Christmas in your mind." This remark effectively reveals that, in Vieno's opinion, a Christmas spent listening to Lutheran hymns and lacking a visit to church was not quite properly celebrated. I would think that 
similar ambiguity often characterized the women's choices concerning religious practice. These choices induced a conflict within the interviewees' habitus, a clash between their dispositions related to the religious field and to the family field. This is implied, for example, in the women's open expressions of joy and satisfaction over the fact that they nowadays had more time and freedom to practice religion than before, when their children had been small.

Throughout this chapter, I have emphasized how the interviewees' religious activity in their adult families took into account their family members and loved ones. The analysis can be read to suggest that the women were performing their actions with simply altruistic motives. However, it must also be kept in mind that the informants did not wholly resign their personal spiritual practices even as mothers of underage (Lutheran) children. Instead, they carved a space for religion in their everyday lives, often showing resilience in holding on to customs experienced as personally important. Furthermore, it is also possible to look at their altruistic activities from an individualistic perspective: to ask what they gained from these activities.

According to many feminist scholars, one problem with Bourdieu's view on the gendered division of labor is his understanding of women as "capitalbearing objects" (Lovell 2000, 37), whose actions are reducible to the transfer of resources (for instance, social skills and cultural know-how) from one generation to the next within the family. Bourdieu, in other words, neglects the possibility that women could also be accumulating power for themselves at the same time as they act (and are being used) as altruistic vessels of capital within the family field (Fowler 2003, 480-482; Lovell 2000, 37-38, 41; Reay 2004a; Skeggs 2004a, 28-29). I consider it important to acknowledge the possible intertwinement of altruistic motives with individualistic ones in the interviewees' actions. Thus, I argue that while the Orthodox women labored to sustain the collective religious lives of their Lutheran or Orthodox families, they also bolstered their own status within these families. They established themselves as organizers and authorities with regard to the structuring of domestic life, family religious affairs, matters of familial tradition, the raising of children, and the cultivation of kinship relations. This is a good example of how agency is created contextually: of how the formation of the habitus both subjects the individual to particular power relations and imbues him or her with agentic capacities. In the adult family context, the women's responsibilities as workers, mothers, and wives took priority over their personal religious practice. Nevertheless, these same responsibilities also placed them in a pivotal position within the domestic and personal lives of their families (see also di Leonardo 1987, 443, 451). In other words, they facilitated the interviewees' accrual of certain power and resources on the family front. 